\title{
Arthropod diversity associated with infestation spots of fig tree borer under rain-fed conditions of Maged valley, Matrouh, Egypt
}

\author{
Imam, A. I. ${ }^{1}$ and Rabab F. Sawaby ${ }^{2}$ \\ 1- Plant Protection Department, Desert Research Center, Mataria, Cairo, Egypt \\ 2- Entomology Department, Faculty of Science, Ain Shams University, Cairo, Egypt
}

\section{ABSTRACT}

Fig orchards (beside olive ones) constitute the main agriculture component along the Egyptian north western coast. Fig tree borer; Trichoferus gracious (Fabricius, 1792) (Order: Coleoptera, Family: Cerambicidae) considers as one of the highest dangerous pests attacking fig tree. Through regarding arthropod diversity associated with infestation spots of $T$. gracious, obtained data showed that, recovered species were belonged to 9 orders. Among them, order Coleoptera was the highest represented, which repeated 18 times throughout the whole investigation period. Total numbers of detected species were 20 ones, from which coleopteran and hymenopteran species occupied the maximum share by 7 species for each order. Recovered individuals were represented by 154 ones. Among them coleopteran individuals with 46 total detected ones came on the top of the list. Among such arthropods, beneficial species was of higher dominance and abundance than herbivorous ones. Although data revealed that, T. griseus was of low dominance and abundance percentages, it was the only primary herbivorous species that responsible for opening the way for the other herbivores ones to perform their damages.

Keywords: Fig tree orchards, Fig tree borer, Trichoferus gracious (Order: Coleoptera, Family: Cerambicidae), Arthropod diversity, Rain-fed irrigation, North western coast, Matrouh Governorate and Egypt.

\section{INTRODUCTION}

Throughout the Egyptian north western coast that extended from west of Alexandria to Matrouh Governorate, fig tree orchards are greatly cultivated. The prevailing environmental conditions characterizes such coast; the high temperature during summer season, the rain-fed irrigation conditions and the rarely agrochemical usage make its fig fruits from the finest ones when compared with that produced from other fig cultivation localities (Shahein et al., 1993). Among fig tree attacking pests, fig tree borer; Trichoferus gracious (Fabricius, 1792) (Order: Coleoptera, Family: Cerambicidae) considered as one of the highest dangerous pests. According to GulZumreoglu (1975), hatched larva initially feeds on the bark and later enters the wood and chews its way through the wood, forming tunnels as it does so. The larva packs excrement (frass) and castings behind it as it burrows and pushes some of them through small holes in the bark. Larval development takes from 2.7-2.8 years. Such internal feeding habit constitutes a safe harbour for the larval stage that makes its control process so difficult. At full grown stage, the larvae tunnel to just beneath the bark where they moult into pupae. By pupating under the bark, they can make an easy exit when they emerge as adults. The pupal developmental period lasts 89-99 days. The adult form develops inside the pupa and on maturity emerges. The female then needs to mate with a male and find suitable sites on host plants for laying her eggs (Hoskovec and Rejzek, 2001). 
Continuous monitoring of the infestation spots of this borer on fig tree trunk gain much interest owing to the diverse dynamic state of arthropods that resort to such spot after T. gracious larval infestation. Where, this infestation spot, due to Trichoferus larval chewing, was of soften tissues that open the way for vast arthropod species to survive. Accordingly the present study aimed to explore the arthropod diversity associated with infestation spots of fig tree borer that may give an obvious insight about the timing of fig borer adult emergence under the Egyptian north western coast conditions, other fig trunk attacking pests and beneficial species that associated with fig borer infestation spots.

\section{MATERIALS AND METHODS}

\section{Study site and sampling method}

In the west direction and at a distance of about $20 \mathrm{~km}$ from Marsa Matrouh city, Maged valley was chosen to carry out this experiment. This experimental site is characterized by large extension of fig orchards that subjected to all agricultural practices performed through the north coast (rain-fed irrigation and rareness usage of fertilizers and insecticides). In this experimental location, sampling was done from last October 2011 to July. 2012.

\section{Experimental design}

Through biweekly picked samples, infestation spots of 5 fig trees were inspected. The inspection process was carried out through using sharp agricultural sickle. Where, as fig borer larva chews its way through the wood, eroded or lacerated tissues at such infestation spot was cleaned or sanitized and all found insects were collected into plastic jar. Sanitation of such infestation spot was continued till reaching the larval stage of the borer. In case of no borer larva was found, sanitation process was continued till reaching the end of the tunnel. Inspection process of arthropods was postponed during the period of dust storm blowing that took about one to two days then continued promptly after the end of the storm.

\section{Arthropod identification}

Collected adult specimens were killed using 70\% ethanol solution, whereas collected immature stages were incubated and supplied with suitable food till adult emergence. Such arthropods were categorized according to Maleque et al. (2007) to functional groups based on feeding habits: herbivores, beneficials and scavengers. Number of individuals and species of each sample were recorded. All collected arthropods were identified to families based on specific identification keys. Identification of collected arthropods was carried out using the following keys; Borror et al. (1976), Imms (1977), Mohammad et al. (2001) and The Fauna Europaea database (2004).

\section{Dominance and abundance percentages of collected arthropods}

Dominance percentages (D\%) of collected arthropods were determined according to Fernando and Alberto (2012) as follow:

$$
\mathrm{D} \%=(\mathrm{n} / \mathrm{N}) \times 100 \quad \text { Where, }
$$

$\mathrm{n}$ : The total number of individuals per taxon.

$\mathrm{N}$ : The total number of individuals of all taxa sampled.

Calculated dominance percentages were categorized as follow:

$\mathrm{db} \%=(\mathrm{Ba} / \mathrm{Bb}) \times 100$

$\mathrm{dh} \%=(\mathrm{Ha} / \mathrm{Hb}) \times 100$ Where,

$\mathrm{db} \%$ : Dominance percentage of a beneficial taxon as compared with total number of collected beneficial taxa. 
Ba: Total number of the beneficial taxon.

Bb: Total number of collected beneficial taxa.

dh\%: Dominance percentage of a herbivorous taxon as compared with total number of collected herbivorous taxa.

Ha: Total number of the herbivorous taxon.

$\mathrm{Hb}$ : Total number of collected herbivorous taxa.

Abundance of collected arthropods were determined according to Facylate (1971) equations as follow:

$\mathrm{ab} \%=(\mathrm{n} / \mathrm{N}) \times 100 \quad$ Where,

$\mathrm{ab} \%=$ Abundance percentage of an arthropod species.

$\mathrm{n}=$ Number of samples in which the species appeared.

$\mathrm{N}=$ Total number of samples.

\section{RESULTS AND DISCUSSION}

Through periodical monitoring of arthropods harboured infestation spots of fig tree borer, the point that gained much interest was the high diversity of the detected arthropod orders. Representation of arthropod orders that detected in association with such infestation spots was declared in Table (1). The detected arthropod was 9 orders, which arranged in a descending manner according to their frequencies (incidence) throughout the whole study period. Among the detected species, order Coleoptera was the highest represented. Where, through the whole study period that extended along 13 inspection dates, Coleoptera order was repeated (frequenced) 18 times. The second category was occupied by both Hymenoptera and Arachnidae that were repeated 12 times for each, whereas with 5 times repetition, order Lepidoptera came in the third rank. Among the total detected orders, Coleoptera occupied about 34.62 representation percentage, whereas the other two orders were represented by $23.08 \%$ for each (Fig., 1). The reminder orders were repeated once.

Table 1: Representation percentages of detected arthropod orders associated with infestation spots of fig tree borer, Matrouh Governorate, Egypt.

\begin{tabular}{|c|c|c|c|c|c|c|c|c|c|c|}
\hline Detected orders & $\begin{array}{l}\frac{\pi}{0} \\
\stackrel{\tilde{a}}{0} \\
\stackrel{0}{0} \\
0\end{array}$ & 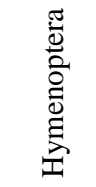 & 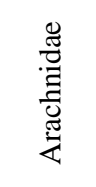 & 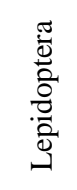 & 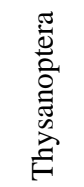 & 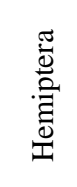 & 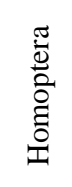 & 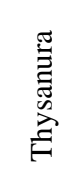 & 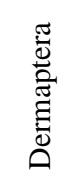 & Total \\
\hline Frequency & 18 & 12 & 12 & 5 & 1 & 1 & 1 & 1 & 1 & 52 \\
\hline \% representation & 34.62 & 23.08 & 23.08 & 9.62 & 1.92 & 1.92 & 1.92 & 1.92 & 1.92 & 100.00 \\
\hline
\end{tabular}

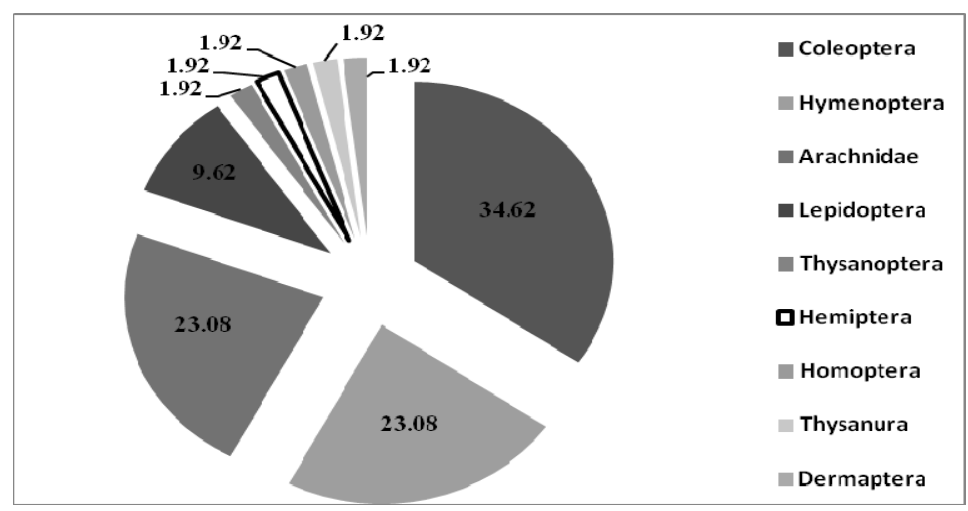

Fig. 1: Representation percentages of the detected orders associated with infestation spots of fig tree borer. 
Through considering the detected species, two main topics were considered; the numbers of detected species and the number of individuals of each species. The numbers of detected species were considered for all detected orders except for Arachnidae due to the inability for identifying its species, whereas species of the other orders that didn't completely identified were represented either by their suborders or super families or families. As shown in Table (2), the total numbers of detected species were 20, from which coleopteran and hymenopteran species occupied the maximum share (contribution) by 7 represented species for each order. Such species were equally represented by 35\% from the total detected species (Fig. 2). The contribution of the reminder orders were restricted on 6 species (one species per each order), which had $30 \%$ total representation from the total collected species.

Table 2: Representation percentages of detected arthropod species of each order associated with infestation spots of fig tree borer, Matrouh Governorate, Egypt.

\begin{tabular}{|c|c|c|c|c|c|c|c|c|c|}
\hline & $\begin{array}{l}\frac{\pi}{0} \\
\stackrel{0}{0} \\
\frac{0}{0}\end{array}$ & 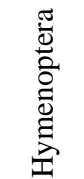 & 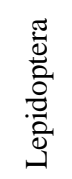 & 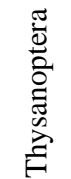 & 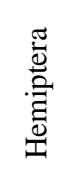 & 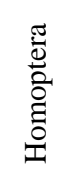 & 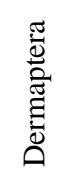 & 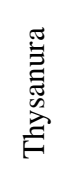 & Total \\
\hline No. of species & 7 & 7 & 1 & 1 & 1 & 1 & 1 & 1 & 20 \\
\hline $\begin{array}{c}\% \\
\text { representation }\end{array}$ & 35.00 & 35.00 & 5.00 & 5.00 & 5.00 & 5.00 & 5.00 & 5.00 & 100.00 \\
\hline
\end{tabular}

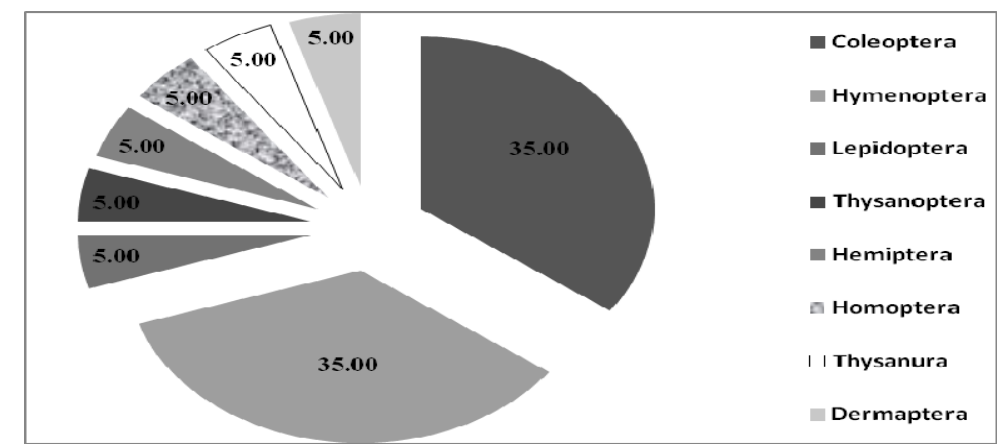

Fig. 2: Representation percentages of the detected species numbers of each order associated with infestation spots of fig tree borer.

Through regarding the collected individuals, Table (3) showed that, such individuals were represented by 154 ones. Coleopteran individuals with 46 total detected ones came on the top of the list. As both Hymenopteran and Arachnid individuals occupied the second and third levels by 43 and 38 represented individuals, respectively, each of Lepidopteran (16 individuals) and Homopteran (6 individuals) ones came in the fourth and fifth ranks. Except for Thrips tabaci Lindeman, 1889 (O.: Thysanoptera, F.: Thripidae) that represented by 2 individuals, reminder orders were represented by only one individual. Individual representations of each recovered species were illustrated in Table (3). 
Table 3: Numbers of the detected individuals of each species associated with infestation spots of fig tree borer and its dominance percentage (D\%), Matrouh Governorate, Egypt.

\begin{tabular}{|c|c|c|c|c|c|}
\hline Order & Family & Species & $\begin{array}{l}\text { Number of } \\
\text { individuals }\end{array}$ & Total & $\mathrm{D} \%$ \\
\hline \multirow{7}{*}{ Coleoptera } & Tenebrionidae & Tribolium sp. & 1 & \multirow{7}{*}{46} & 0.65 \\
\hline & & F.: Dermestidae* & 6 & & 3.90 \\
\hline & Tenebrionidae & Tentyria sp. & 30 & & 19.48 \\
\hline & Cerambycidae & Trichoferus griseus (Fabricius, 1792) & 3 & & 1.95 \\
\hline & \multicolumn{2}{|c|}{ F.: Tenebrionidae, S. f.: Opatrinae* } & 4 & & 2.60 \\
\hline & \multicolumn{2}{|c|}{ F.: Bruchidae* } & 1 & & 0.65 \\
\hline & \multicolumn{2}{|r|}{ Unknown** } & 1 & & 0.65 \\
\hline \multirow{7}{*}{ Hymenoptera } & Chalcididae & Brachymeria sp. & 2 & \multirow{7}{*}{43} & 1.30 \\
\hline & Formicidae & Monomorium carbonarium (Smith, 1858) & 33 & & 21.43 \\
\hline & Cephidae & Cephus sp. & 2 & & 1.30 \\
\hline & \multicolumn{2}{|r|}{ S. O.: Apocrita* } & 1 & & 0.65 \\
\hline & Formicidae & Lepisiota sp. & 3 & & 1.95 \\
\hline & Formicidae & Cardiocondyla wroughtonii (Forel, 1890) & 1 & & 0.65 \\
\hline & Formicidae & Tetramorium brevicorne, Brondroit, 1918 & 1 & & 0.65 \\
\hline Arachnidae & \multicolumn{2}{|r|}{ Unknown } & 38 & 38 & 24.68 \\
\hline Lepidoptera & Gelechiidae & Platydera sp. & 16 & 16 & 10.39 \\
\hline Homoptera & \multicolumn{2}{|r|}{ Unknown** } & 6 & 6 & 3.90 \\
\hline Thysanoptera & Thripidae & Thrips tabaci Lindeman, 1889 & 2 & 2 & 1.30 \\
\hline Hemiptera & \multicolumn{2}{|r|}{ F.: Lygaeidae* } & 1 & 1 & 0.65 \\
\hline Thysanura & Lepismatidae & Lepisma sp. & 1 & 1 & 0.65 \\
\hline Dermaptera & Forficulidae & Forficula sp. & 1 & 1 & 0.65 \\
\hline \multicolumn{4}{|c|}{ Total } & 154 & \\
\hline
\end{tabular}

Dominance percentages of each species (D\%) were calculated and also illustrated in Table (3). Recovered arthropod species as shown in Table (4) were categorized into primary pests, secondary pests, natural enemies and scavengers and the total dominance percentage of each category were calculated. The point that gained much interest was that, beneficial species were the most dominant ones. Where, through observing data in Tables (3 and 4), it was easy to conclude that, each of Arachnid and Monomorium carbonarium (Smith, 1858) beneficial species through their 24.68 and 21.43 dominance percentages, respectively in addition to the minor dominance percentages of the other beneficials put beneficial species of more diverse than herbivorous ones. Such idea was confirmed through categorize such herbivores into primary and secondary ones. That is to say, although Trichoferus griseus was of low dominance percentage $(1.95 \%)$, it is the only primary herbivorous species that responsible for opening the way for the other herbivores ones to perform their damages. Accordingly, it is worth to differentiate between the dominant herbivorous species and that caused economic losses. That is to say, although both Tentyria sp. (O.: Coleoptera, F.: Tenebrionidae) and Platydera sp. (O.: Lepidoptera, F.: Gelechiidae) were the highest dominant herbivorous species with 19.48 and 10.39 dominance percentages, respectively, but they were of minor role through considering their induced losses especially when compared with that caused by T. griseus with 1.95 D\%. In Harmony, Iwata et al. (1997 and 1998) stated that, although the very population density of Xylotrechus villioni (Villard) (Coleoptera: Cerambycidae), its cumulative damage was observed on coniferous tree branches i.e., of the 14 major branches in one sample tree, six had cumulative damage by boring larvae, of which 3 had been bored by multiple larvae. Through considering the total dominance percentages of the four pre-mentioned categories, Table (4) declared that, natural enemies were the highest domain species $(\mathrm{D} \%=51.31 \%)$ followed by secondary 
pests and scavenger species with 42.22 and $4.55 \%$, respectively. The lowest represented species was the primary pest, $T$. griseus.

Table 4: Total dominance percentages (D\%) of arthropod species associated with infestation spots of fig tree borer, Matrouh Governorate, Egypt.

\begin{tabular}{|c|c|c|c|c|}
\hline \multirow{12}{*}{ 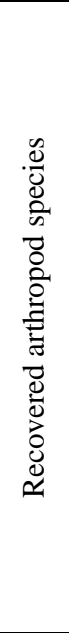 } & $\begin{array}{l}\text { Primary } \\
\text { pests }\end{array}$ & Secondary pests & Natural enemies & Scavengers \\
\hline & \multirow{11}{*}{ 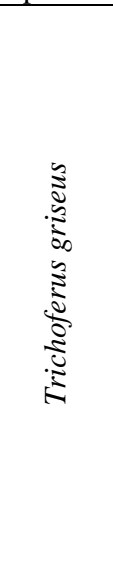 } & Tribolium sp. & Brachymeria sp. & F.: Dermestidae \\
\hline & & Tentyria sp. & $\begin{array}{l}\text { Monomorium } \\
\text { carbonarium }\end{array}$ & Lepisma sp. \\
\hline & & $\begin{array}{c}\text { F.: Tenebrionidae, S. f.: } \\
\text { Opatrinae }\end{array}$ & S. O.: Apocrita & \\
\hline & & F.: Bruchidae & Lepisiota sp. & \\
\hline & & $\begin{array}{c}\text { Unknown Coleopteran } \\
\text { species }\end{array}$ & $\begin{array}{c}\text { Cardiocondyla } \\
\text { wroughtonii }\end{array}$ & \\
\hline & & Cephus sp. & Tetramorium brevicorne & \\
\hline & & Platydera sp. & Arachnid species & \\
\hline & & $\begin{array}{l}\text { Unknown Homopteran } \\
\text { species }\end{array}$ & & \\
\hline & & Thrips tabaci & & \\
\hline & & F.: Lygaeidae & & \\
\hline & & Forficula sp. & & \\
\hline D\% & 1.95 & 42.22 & 51.31 & 4.55 \\
\hline
\end{tabular}

In Table (5) dominance percentage of each herbivorous (dh\%) and beneficial $(\mathrm{db} \%)$ taxon as compared with total number of collected herbivorous and beneficial arthropod taxa were illustrated, respectively. Among the recovered herbivores, Tentyria and Platydera species was the highest dominant species by 44.12 and $23.53 \%$, respectively. Whereas, dominance percentage of $T$. griseus put it among the lowest dominant species by $4.41 \mathrm{dh} \%$. Through considering the recovered beneficials, Table (5) revealed that each of Arachnid predacious spiders and $M$. carbonarium were the highest dominant species among the detected beneficials.

Table 5: Dominance of herbivorous (dh\%) and beneficial (db\%) species associated with infestation spots of fig tree borer, Matrouh Governorate, Egypt.

\begin{tabular}{|c|c|c|c|}
\hline \multicolumn{2}{|l|}{ Herbivores } & \multicolumn{2}{|l|}{ Beneficials } \\
\hline Herbivorous species & $\mathrm{dh} \%$ & Beneficial species & $\mathrm{db} \%$ \\
\hline Tribolium sp. & 1.47 & Brachymeria sp. & 2.53 \\
\hline Tentyria sp. & 44.12 & Monomorium carbonarium & 41.77 \\
\hline Trichoferus griseus & 4.41 & S. O.: Apocrita & 1.27 \\
\hline F.: Tenebrionidae, S. f.: Opatrinae & 5.88 & Lepisiota sp. & 3.80 \\
\hline F.: Bruchidae & 1.47 & Cardiocondyla wroughtonii & 1.27 \\
\hline Unknown Coleopteran species & 1.47 & Tetramorium brevicorne & 1.27 \\
\hline Cephus sp. & 2.94 & Arachnid species & 48.10 \\
\hline Platydera sp. & 23.53 & & \\
\hline Unknown Homopteran species & 8.82 & & \\
\hline Thrips tabaci & 2.94 & & \\
\hline F.: Lygaeidae & 1.47 & & \\
\hline Forficula sp. & 1.47 & & \\
\hline
\end{tabular}

$\mathrm{db} \%$ : Dominance percentage of a beneficial taxon as compared with total number of collected beneficial taxa.

$\mathrm{dh} \%$ : Dominance percentage of a herbivorous taxon as compared with total number of collected herbivorous taxa.

The distribution of the caught individuals of each species throughout the whole investigation period were expressed by the abundance percentage calculations (ab\%) (Table 6). True predacious spiders (O.: Arachnidae) were the highest abundant species with 84.62 ab\%. Both Tentyria and Platydera species by their abundance percentages of 76.92 and $38.46 \%$ s, respectively were the second and third abundant species. As previously mentioned, although $T$. griseus was of less abundance percentage 
(15.38\%), boring or feeding behavior of which was the keystone for the arthropod diversity associated with its infestation spots. Arthropod diversity that harboured Matrouh valleys either endemic or invasive required further studies, which may serve in solving the pest problems that face Matrouh dwelling Bedouins on an environmental bases.

Table 6: Abundance percentages (ab\%) of each species associated with infestation spots of fig tree borer, Matrouh Governorate, Egypt.

\begin{tabular}{|c|c|c|c|c|}
\hline Order & Species & $\mathrm{N}$ & $\mathrm{N}$ & $\mathrm{ab} \%$ \\
\hline \multirow{7}{*}{ Coleoptera } & Tribolium sp. & 1 & \multirow{21}{*}{13} & 7.69 \\
\hline & F.: Dermestidae & 2 & & 15.38 \\
\hline & Tentyria sp. & 10 & & 76.92 \\
\hline & Trichoferus griseus & 2 & & 15.38 \\
\hline & $\begin{array}{c}\text { F.: Tenebrionidae, S. f.: } \\
\text { Opatrinae }\end{array}$ & 2 & & 15.38 \\
\hline & F.: Bruchidae & 1 & & 7.69 \\
\hline & Unknown & 1 & & 7.69 \\
\hline \multirow{7}{*}{ Hymenoptera } & Brachymeria sp. & 1 & & 7.69 \\
\hline & Monomorium carbonarium & 3 & & 23.08 \\
\hline & Cephus sp. & 1 & & 7.69 \\
\hline & S. O.: Apocrita & 1 & & 7.69 \\
\hline & Lepisiota sp. & 1 & & 7.69 \\
\hline & Cardiocondyla wroughtonii & 1 & & 7.69 \\
\hline & Tetramorium brevicorne & 1 & & 7.69 \\
\hline Arachnidae & Unknown & 11 & & 84.62 \\
\hline Lepidoptera & Platydera sp. & 5 & & 38.46 \\
\hline Homoptera & Unknown & 1 & & 7.69 \\
\hline Thysanoptera & Thrips tabaci & 1 & & 7.69 \\
\hline Hemiptera & F.: Lygaeidae & 1 & & 7.69 \\
\hline Thysanura & Lepisma sp. & 1 & & 7.69 \\
\hline Dermaptera & Forficula sp. & 1 & & 7.69 \\
\hline
\end{tabular}

\section{According to the previous data more than one point could be concluded}

1- Removing endemic natural vegetation characterized Matrouh valleys for creating a new mono-crop agricultural profile (fig or olive trees orchards) led to a state of disturbance among all living organisms dwelling such previously balanced system. In harmony, Heyborne et al., (2003) and Ishii et al., (2004) stated that natural, semi-natural and old growth forests include a variety of tree species, shrubs and herbs with variable age classes, providing many habitat sources for forest-dwelling organisms. In contrast, mono-specific, even-aged plantations lack habitat sources and thus support low biodiversity (Kerr 1999). Such agro-ecosystems in Matrouh valleys led to the outbreak of fig tree borer losses in such a way that, great numbers of Bedouins cultivators are seriously thinking to remove their fig orchards (personal communications).

2- During the course of this study, twice detection of fig tree borer adults were observed at October $27^{\text {th }}, 2001$ (one adult individual) and June $9^{\text {th }}, 2012$ (two adult individuals) inspection dates. Such adults were caught underneath fig tree bark and they were ready for flying. Such flight activity season was more or less in harmony with other cerambycid long horned beetles. Where, Pedro et al., (2008) stated that, the emergence pattern of Monochamus galloprovincialis (Coleoptera, Cerambycidae) occurred from May to September with a peak in July, being consistent with the captures of attractive traps.

3- Infestation spot of fig tree borer, T. griseus, due to its soften and deteriorated tissues, open the way for vast arthropod species to survive and accordingly constitutes an ideal harbor for high arthropod diversity. Among such 
arthropod, beneficial species was of higher dominance and abundance than herbivorous ones. The reasonable key point of such note may be the scarcity (rareness) of chemical insecticide practices at north western cost plantations, which may conserve and enhance population build-up of naturally occurring beneficials.

4- It is worth to concentrate all efforts for facing the economically inducing pest even it was of low presentation not for that of false impression, i.e., insects of highly distribution but with low or minor losses.

5- Since Trichoferus griseus usually has a very low population density, its natural enemies cannot live on this cerambycid only. This means that, T. griseus enemies are mostly generalists that are quite indifferent to and independent of T. griseus density. Similar remark was stated by Iwata et al. (1997) through their studying the boring activity of $X$. villioni (Coleoptera: Cerambycidae).

6- Although such beneficial diversity, they fail to combat or decline herbivore inducing damages especially that caused by fig tree borer. Two main reasons may cover such concern; the first may be the incompatibility of such beneficial species with the feeding and behavioural habitats of the pest. The second reason was the non-synchronized state between the appearance of beneficials and herbivores. That is to say, time delay between influx of herbivore population and the reaction of naturally existing beneficials to face pest losses. The expression "too little, too late" was commonly heard in criticism of biological control for the inability of endemic beneficials for controlling certain insect pest population. The lag time for beneficials to react was influenced according to Miles (1987) by population dynamics of insect pest species and predators present, weather conditions, time of year, stage of growth...etc. Hence, this lapse period allowed pest population to exceed the economic threshold and inflicted damage before beneficials again bring the pest into equilibrium.

\section{REFERENCES}

Borror, J. D.; Delong, D. M. and Triplehorn, C. A. (1976): An introduction to the study of insects. New York, 852 pp.

Facylate, K. K. (1971): Field studies in soil invertebrate. $2^{\text {nd }}$ ed. Vishia Shkoola Press, Moscow, USSR.

Fernando, G. S. and Alberto, R. C. (2012): Benthic communities on hard substrates covered by Limnoperna fortunei Dunker (Bivalvia, Mytilidae) at an estuarine beach (Rio de la Plata, Argentina). J. Limnol., 71(1): 144-153.

Gul-Zumreoglu, S. (1975): Investigation on taxonomy, host plants and distribution of the long-horned beetles (Cerambycidae: Coleoptera) in Aegean region. Mins. Agr., Technical Bul., 28, 208 pp.

Heyborne, W. H.; Miller, J. C. and Parsons, G. L. (2003): Ground dwelling beetles and forest vegetation change over a 17-year period, in western Oregon, USA. Forest Ecol. Manag., 179: 123-134.

Hoskovec, M. and Rejzek, M. (2001): Longhorn beetles (Cerambycidae) of the West Palearctic region. (http://www.uochb.cas.cz/natur/cerambyx /index.htm).

Imms, A. D. (1977): A general text book of Entomology. Methuen \& co. LTD. London. 698 pp.

Ishii, H. T.; Tanabe, S. and Hiura, T. (2004): Exploring the relationships among canopy structure, stand productivity and biodiversity of temperate forest ecosystems. Forest Sci., 50: 342-355. 
Iwata, R.; Yamada, F.; Kato, H.; Makihara, H.; Araya, K.; Ashida, H. and Takeda, M. (1997): Nature of galleries, durability of boring scars, and density of Xylotrechus villhmi (Villard) larvae (Coleoptera: Cerambycidae), on coniferous tree trunks. Pan-Pacific Entomologist, San Francisco, 73: 213-224.

Iwata, R.; Sakakibara, Y. and Yamada, F. (1998): Boring activity on coniferous tree branches by Xylotrechus villioni (Villard) larvae (Coleoptera: Cerambycidae). J. For. Res., 3: 247-249.

Kerr, G. (1999): The use of silvicultural systems to enhance the biological diversity of plantation forests in Britain. Forestry, 72: 191-205.

Maleque, A. M.; Ishii, H. T.; Maeto, K. and Taniguchi, S. (2007): Line thinning fosters the abundance and diversity of understory Hymenoptera (Insecta) in Japanese cedar (Cryptomeria japonica D. Don) plantations. J. For. Res., 12: 14-23.

Miles, A. K. (1987): Insect management in cotton. (http://www.osu.altus.ok.us/Chapter\%2012\%20\%20Insect\%20Managent)

Mohammad, S.; Zalat, S.; Fadl, H.; Gadalla, S. and Sharaf, M. (2001): Taxonomy of ant species (Hymenoptera: Formicidae) collected by pitfall traps from Sinai and Delta regions. Egypt. J. Nat. Hist., 3: 40-61.

Pedro, M. N.; Edmundo, S. and José, M. R. (2008): Biology of Monochamus galloprovincialis (Coleoptera, Cerambycidae) in the Pine wilt disease affected zone, Southern Portugal. Silva Lusitana, 16 (2): 133 - 148.

Shahein, A.; Attalla, A. and El Sehrawy, O. (1993): Flower bud initiation and differentiation relation to different soil fertilization treatments for trees of three imported fig varieties grown in King Mariut (Egypt). Alex. J. Agric. Res., 38 (1): 323 - 336.

The Fauna Europeae database (2004): http://www.faunaeur.org.

\section{ARABIC SUMMARY}

$$
\begin{aligned}
& \text { تنوع مفصليات الأرجل المرتبطة ببؤز إصابة حفار ساق التين تحت ظروف الزراعة المطرية }
\end{aligned}
$$

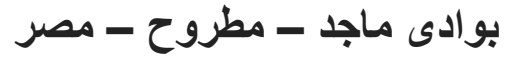

$$
\begin{aligned}
& \text { أحمد إبراهيم إمام } 1 \text { ورباب فتحى صوابى } 2
\end{aligned}
$$

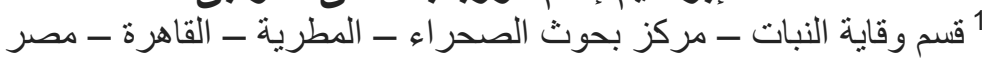

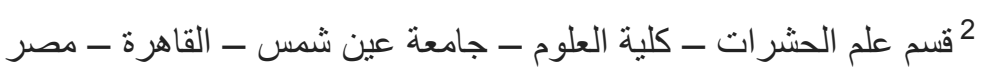

تشكل بساتين أثجار التين والزيتون المكون الأساسى لقوام الزراعة بطول منطقة الساحل الثمالى

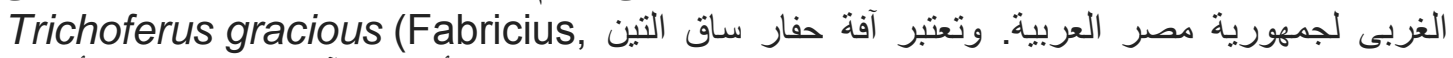
(Order: Coleoptera, Family: Cerambicidae)

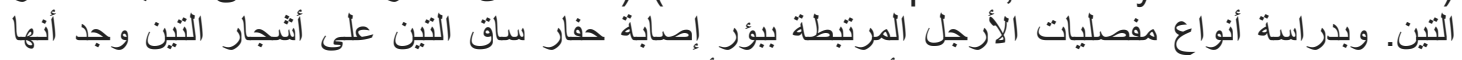

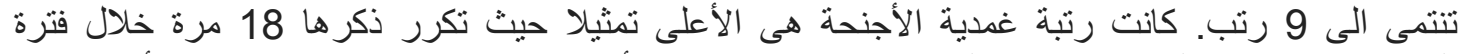

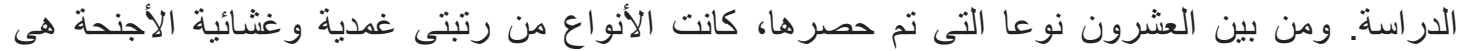

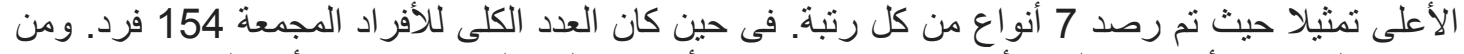

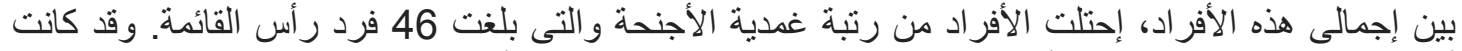

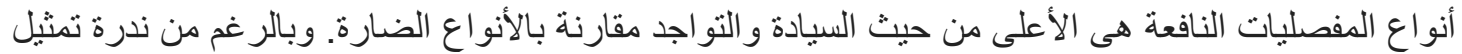

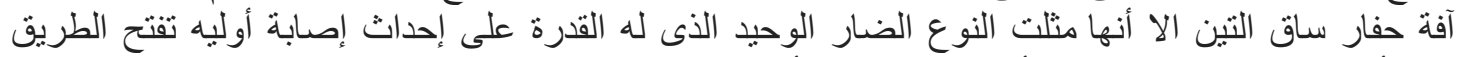

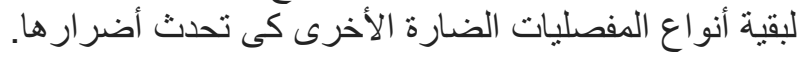

